\title{
Enumeration as Pedagogic Process: Gendered Encounters with Identity Documents in Delhi's Urban Poor Spaces
}

\section{Tarangini Sriraman}

\section{(2) OpenEdition \\ Journals}

Electronic version

URL: http://journals.openedition.org/samaj/3655

DOI: $10.4000 /$ samaj.3655

ISSN: 1960-6060

Publisher

Association pour la recherche sur l'Asie du Sud (ARAS)

\section{Electronic reference}

Tarangini Sriraman, «Enumeration as Pedagogic Process: Gendered Encounters with Identity Documents in Delhi's Urban Poor Spaces », South Asia Multidisciplinary Academic Journal [Online], 8 | 2013, Online since 19 December 2013, connection on 21 April 2019. URL : http:// journals.openedition.org/samaj/3655 ; DOI : 10.4000/samaj.3655

This text was automatically generated on 21 April 2019.

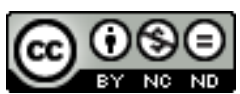

This work is licensed under a Creative Commons Attribution-NonCommercial-NoDerivatives 4.0 International License. 


\title{
Enumeration as Pedagogic Process: Gendered Encounters with Identity Documents in Delhi's Urban Poor Spaces
}

\author{
Tarangini Sriraman
}

Shweta, ${ }^{1}$ a resident of Govindpuri cluster, had encountered a series of frustrations in her attempts to get a ration card. ${ }^{2}$ She told me that her employer in whose house she worked as a help, had kindly agreed to let her use his residential address. Having such an address is indispensable in applying for any identity document in India. Shweta could not afford the dalal (middleman) who had offered to expedite her access to food officials at the local ration card office in Govindpuri, in South Delhi. She had also gone as far as the house of her ward councillor to request his assistance in getting a card made. Shweta did not know, however, that Below the Poverty Line (BPL) ration cards ${ }^{3}$ were not currently being issued by the Delhi government in slums. A new survey needed to be taken and only then would fresh cards be issued. But when I told her this, Shweta looked puzzled. For a long time she had considered her inability to get an identity card to be the marker of her poverty. And now I was telling her that it was because she was not counted poor that she could not get a ration card. She was very clear in her mind that it was because she had no identity card that she could not become dilli ki gareeb nagarik (a poor citizen of Delhi). ${ }^{4}$ Those citizens who possessed documents-and were citizens by that token-were better off than those who were entirely disenfranchised and had no claim to state services, in her estimation. She was estranged from her husband and could not use his previous proofs to get a document like the voter identity card issued in her name. If only she got the voter identity card, she could have used it as a breeder document (one which sufficed as proof for other documents). Owing to her ongoing failure to get any identity document of note that would ease her access to the city, Shweta had come to react adversely to the word 'proof'. This word jarred all the more because of all the welfare benefits that have 
eluded her as an urban poor subject, as a woman, and as a woman with no ties to her husband's documents.

Through the case study of enumeration initiatives undertaken in a slum cluster in Govindpuri, South Delhi, this paper seeks to show how the experiences-with regard to documentary proof-that urban poor women residing in the city's margins have had are constitutive of a 'pedagogic process'. Whenever Shweta approached her landlord, a middleman or a councillor, she was in the act of engaging in piecemeal pedagogies: those incremental practices which are immersed in the minute and the everyday aspects of urban life. Piecemeal pedagogies could range from invoking hierarchy, citing political affiliations, and making veiled threats to expose the incompetence of officials and dealers, to employing the right type of body language and drawing on various forms of literacy. The spaces in which such pedagogies are forged are equally varied: they encompass but are not confined to the ration office, the Fair Price Shop (FPS), Delhi's housing authority offices, the police station, mahila mandal (women's council) meetings and informal gatherings in slum alleys. The existence of these pedagogies may seem commonplace and even trivial because they amount to small-scale strategizing. But piecemeal pedagogies are in no way different from the mobilisation of key resources in the slum, mobilisations which are crucial to the pedagogic process of forming understandings of citizenship, gendered governance and patriarchal inflections of bureaucratic institutions.

\section{Piecemeal pedagogies}

3 Shweta's aversion to the word 'proof' may be evocative of an argument by Gaston Gordillo in his paper on identity paper fetishism in Argentinean Chaco. Ethnic indigenous groups displayed a certain reverence and fear towards the documents they possessed or lacked. They brandished their cards proudly without being asked and blamed (the lack of) identity cards for their poverty and susceptibility to violence. Gordillo argues that they did this because they did not fully comprehend the capitalist relations of landencroaching settlers and wage labour were behind the state-issued documents that brought about their alienation from citizenship claims (Gordillo 2006: 164). The experience of being systematically written out of the constitution and edged out of land ownership made them render documents into objects of reified state authority. In their fetishistic attitude to documents, these ethnic groups do not regard the unequal social relations and conventions of colonizing and capitalist rule, he argues. My paper offers a somewhat different analysis of the relationship between the urban poor, especially urban poor women and identity documents. While Gordillo's thesis may be insightful about the prevalence of invisible social relations and conventions, it pays less attention to how poor subjects develop creative practices, resourceful navigations and step-by-step accumulative processes to acquire, renew and produce identity documents. It is in this regard that I coin the term 'piecemeal pedagogies' or incremental means of engaging with documentary processes. Piecemeal pedagogies are, however, just the starting point of this paper-they can be opened out to allow an examination of various social dynamics of literacy, class, caste and their embedded operation within gender frameworks.

4 I use this term 'pedagogic process' to illuminate the subterranean and quotidian 'learning of the ropes' of navigating dense bureaucratic networks in obtaining identity documents and producing written proof to avail benefits. The various encounters of urban poor 
residents with identification documents produce certain instrumental and thick forms of knowledge about the city. Instrumental forms of knowledge are encapsulated by 'piecemeal pedagogies', which are the common practices of educating oneself and fellow female slum residents in and through handling documents. 'Enumeration as pedagogic process' gestures at how urban poor women's encounters with ID documents enable piecemeal advances in the learning of tactics of wresting entitlements, recognizing official hierarchies, employing appropriate vocabularies of power in bureaucratic offices. Beyond such tactics, the process of learning is much weightier in that it engenders the formation of thick knowledge about the city and produces gendered narratives of entitlement and access. Enumeration is a pedagogic process in a more profound sense, in that slum dwellers can observe, gain insights and alter their beliefs about broad structures, practices and norms of gender, social institutions, governance, citizenship and urban belonging. This paper will show how the pedagogic process accrued by enumerative experiences was manifest in a wide range of institutional, informal and official encounters of the urban poor.

5 The pedagogic process is framed by the unreliability of political patronage in the face of arbitrary selection of welfare beneficiaries, gender-insensitive governance and the shifting economies of enumeration in a slum setting. The pedagogic process also presupposes the deep engagement of women with various forms of literacy. This paper considers various imperatives of female literacy in the slum cluster ethnographically, laying out definitions of conventional and political literacy, as well as what kinds of piecemeal and thick pedagogies are rendered possible by the complex relationship between these literacies. This paper tracks the pedagogies of ID documents in the lives of the city's urban poor women over the last two decades, which have been marked by changing technologies of enumeration.

\section{Framing identity documents in global and regional ethnographies}

6 Scholars theorising the political and anthropological possibilities of identification documents in the global south mark out the significance of social conventions and social relations in manoeuvring tight document regimes (Gordillo 2006, Bakewell 2007, Koster 2013). For instance, despite tough immigration laws, traditional chiefs and headmen enjoy leeway in facilitating document acquisition in Northwest Zambia for refugees and their children migrating across Angola (Bakewell 2007). Slum dwellers seek to forge personalised ties of intimacy with police personnel and state functionaries through the sphere of unofficial practices in Brazil surrounding their identity cards (Koster 2013). Following this literature, I argue that the pedagogic process (learning through struggles around identity documents) unfolds itself through various social relations, such as placing trust in one's caste or community leaders, slum leaders, using one's political party leverage or affiliation with informal organisations to claim benefits. Simultaneously, this paper seeks to address a gendered silence in such scholarship's overarching arguments about how citizenship and social relations pierce state-calibrated documentary procedures.

7 On a regional level, scholars have reflected on the habitus of unofficial or quasi-legal identity documents in the everyday. Some scholars show that the state privileging of 
acquisition and production of documents has often created the conditions for others to imitate and reproduce documents illegally. In Indian urban poor spaces, spectatorship, trickery, mimetic performances and even self-enumeration (Appadurai 2001, Tarlo 2003, Anjaria 2011, Srivastava 2012) have been broadly discussed as modes of sometimes subverting procedure, but mostly, wresting entitlement. This paper seeks to complement this scholarship by underlining another often-overlooked modality of seeking entitlement, namely that of the pedagogic process.

In the rural context of a sub-district in the northern Indian state of Uttar Pradesh, Akhil Gupta (2012) critically analyses the mandate for proof and written complaints in everyday claims of rural poor entitlement. As I will demonstrate, Gupta's observations on the reification of bureaucratic modes of writing, the poor's lack of politically and socially relevant literacy and different forms of capital are equally helpful in urban poor spaces. This paper attempts to re-negotiate Gupta's position on literacy-as having to do with knowledge of government procedures as well as the ability to read and write and educational qualifications (Gupta 2012: 179)-to posit literacy in terms of pedagogy. If this paper considers various kinds of literacy to be complementary to each other, it also considers them to be the outcome of various kinds of education, formal education, participation in NGO activities and political party membership. ${ }^{5}$ The process of acquiring literacy (constituted by reading, writing, comprehending texts, and learning about the workings of bureaucracies in urban poor spaces) could not be separated from the process of mobilizing documents and recognizing the resources that they represent.

\section{The field site}

9 The site of my fieldwork is a slum cluster located in Govindpuri in South Delhi which is comprised of three camps, namely, Navjeevan camp, Nehru camp and Bhoomiheen camp, each of which is divided into different Blocks. ${ }^{6}$ The cluster is among Delhi's slum settlements which do not fall under the definition of 'notified slum areas' in the Slum Improvement and Clearance Areas Act, 1956 and is hence ineligible for legal benefits (Chandola 2012: 394). Many of the residents in the cluster were informal workers in the neighbouring industrial area of Okhla in glass and steel factories and garment export houses. Others worked as domestic helps or drivers for neighbouring middle class residents in Govindpuri. The ethnic, religious, caste and linguistic composition of the residents in the three camps is diverse. In the estimate of a local pradhan (unelected slum leader), $60 \%$ of the total families in the cluster come from lower-caste and backward class communities like Chamars, Bhangis, Valmikis, Jatavs, Kahars and Namasudras. This paper draws on conversations spread across two years ${ }^{7}$ with residents of all three camps, food and housing officials and NGO representatives. I spoke to respondents from approximately 70 families spread across these camps. In outlining the narratives of female slum residents, I have changed the names of all respondents to protect them from any consequences their shared conversations might have.

Demolitions never took place in the heart of this cluster though they were recorded by residents to have taken place in the fringes of the cluster three times. ${ }^{8}$ Notwithstanding this lack of demolitions, slum residents were routinely surveyed by housing authorities for potential resettlement. In January 1990, the then-Prime Minister of India, V.P. Singh made a historic announcement that every slum resident would be issued, in addition to a ration card, an identity card and a metallic token on which was inscribed a number or an 
identity for every home (The Hindustan Times 1990). The ration card and identity card issued in 1990 became the basis for various classifications and families had to produce one of these documents to demonstrate proof of continuous residence. Those who were not present during the 1990 initiative were placed into separate brackets of potential resettlement where their chances were either diminished or less substantial compared to those who possessed the ID card. ${ }^{9}$ In 2004-5, Delhi's Planning Department issued instructions to assign a plot of land, 18 square metres in area, to those possessing ration cards, with the cut-off date 31st January 1990, while those possessing ration cards post-1990 and up to December 1998, were to be given 12.5 square metre plots. ${ }^{10}$ Ration cards were thus cast into various urban poor realms of the everyday where they doubled up to assure food security and extend the tenuous promise of resettlement. There is one other, somewhat obscure, dimension of the ration card that I excavated in my fieldwork, namely that of bail. The practice of using one's ration card to obtain bail was common in the $80 \mathrm{~s}$ and the 90s. But how much of a challenge was it for women to exercise this entitlement?

\section{Women's incremental mobilisation of resources}

11 In the first part of the 2000s, when many families did indeed possess functional ration cards in slums, they were often confronted with prospects of delay in getting names added or deleted, not getting rations on time, or getting defrauded or denied rations on arbitrary grounds. These predicaments often forced the emergence of piecemeal pedagogies in the cluster, through which many residents sought to educate each other about how to fill in application forms, how to present applications with the 'right attitude', and how to provoke responsible and responsive conduct in official and unofficial spaces. These pedagogies were equally important for women to navigate starkly male-dominated sites of paperwork and official presence such as police stations and ration offices.

There is a slow accumulation of resources inherent in the piecemeal pedagogies that were used by women to arm themselves against the discriminatory world of bail, policemen and First Information Reports (FIRs). Women's emphasis is as much on acquiring the confidence as the know-how to confront bureaucratic procedures, rough policemen and legal protocols. Piecemeal pedagogies accrued through interlocked informal and formal processes-of chance meetings and note-sharing in by-lanes, alleys and in each other's homes, as well as in institutional settings provided by working in an NGO or in a low-end government job like the balwadi (pre-school teaching) programme. Vocational learning and neighbourly solicitude were not contradictory or distinct from each other. These sets of interactions mingled with each other and prepared women better for eventual confrontations at forbidding sites of bureaucracy.

13 A common sight in the cluster was women walking briskly, clutching some parchi (document) or the other, headed towards either the ration office, a school, dispensary or simply to a neighbour's house to exchange stories of denial, victory and perseverance in securing, altering, or renewing a document. Every trip to a government office required homework. This meant elaborate consultations with neighbours, putting together all manner of residence and identity proof, and sometimes acquiring a recommendation letter from a pradhan (unelected slum leader) or municipal councillor. Women in Govindpuri slowly imbibed knowledge of the various resources that identification 
documents constituted. In the 1980 s and 1990s, a peculiar documentary practice surrounding the ration card was observed, namely, the taking out of bail. My fieldwork indicated that this practice had its place in the margins of the law. Up until the year 1999, the ration card could be used for official and popular purposes like verifying housing claims and taking somebody out on bail. However, the Delhi Specified Articles (Regulation of Distribution) Amendment Order, 1999, inserted a clause that 'the authorised document shall not be valid for any purpose other than for obtaining supplies of specified articles'. ${ }^{11}$ The first food-related Control Order in which the terms Above Poverty Line (APL), Below Poverty Line (BPL) and Antyodaya Anna Yojana (AAY) ${ }^{12}$ feature, in 2001, also put an end to the use of the ration card for identification purposes, stating that it could be used just for the withdrawal of rations. ${ }^{13}$

A struggle to be enumerated often entailed struggles to accumulate the cultural capital that was necessary to be heard by an official or to be taken seriously by police personnel. The pedagogic process of acquiring such capital was hazardous for many women in the cluster who had to demonstrate remarkable fortitude in unfamiliar and hostile environments where they were often intimidated and harassed for bribes. Rakhi, one of the women in Manorama's house, told the others how she once risked getting beaten up by policemen when she took her damad (son-in-law) out on bail. Knowing fully well that they would demand proof and especially her ration card, she took a whole stash of documents (V.P. Singh card, ration card, etc.) and rushed to the local police station. Even then, the police refused to let him off; maybe, they expected a bribe. To quote Rakhi:

I summoned all my courage and called up a lawyer I knew then and there in front of the police, and after calling him up, I told the police firmly that I would go, with my lawyer, to Tees Hazari Court to apply for bail there. It was only then that they let him off on kacchi zamanat (loose or quasi-legal bail). They put a mohur (stamp) on his arm. The stamp will fade away in a few days. ${ }^{14}$

Rakhi added that she knew she had to seem self-assured and even mildly intimidating in her bodily gestures. When asked what the stamp contained, she said the policemen inscribed various details on her son-in-law's hand like where he stayed and the ration card number. Apart from this, Rakhi's ration card was stamped indicating that she had exercised her entitlement to take someone out on bail and could no longer do so for anybody else. Sharda, also a resident of the cluster explained the difference between kacchi zamanat, which one acquired from a thana (local police station) where presumably this practice of inscription prevailed and pukki zamanat (sturdy or legally recognized bail), which one acquired in a Court where one also produced one's ration card but where the bail was less flimsy, legally speaking.

Rakhi and Sharda had both been associated with different welfare bodies at different points in time. Sharda had worked with a clinic as well as an NGO called Community and Sponsorship Program (CASP), which had been active in the cluster in the 1980s and 1990s. Rakhi was a balwadi teacher. To quote her,

We balwadi teachers had fought a case to get our salaries increased in 1999. The case went on for a few years, but I learnt a thing or two about how to handle Court and policewallahs during this time, what tone and manner to use. ${ }^{15}$

It was Sharda and not her husband, a tailor who 'did not go out that much', who filled in most of the forms and it was also she who did the bhagdaud (running around) for the ration card which she obtained two and a half years after she had applied for it. Sharda said, 'Initially, I was afraid of policemen, but working in Asha Clinic gave me some 
courage'. ${ }^{16}$ She explained that her job as a health volunteer required her to present grievances to officials and speak informally to a lot of families about diseases, clean water, nutrition, etc. 'We were trained in Asha Clinic to take photocopies of documents and signatures wherever we went. 'Whatever petition you submit, they will ask you for proof', we were taught in the clinic', she observed. Sharda and Rakhi, who know a good deal about bail procedures, spoke of how their institutional learning was cemented by numerous conversations with women whose male relatives struggled to come out of jail. Field visits by women like Sharda and Rakhi to various slum residences, which formed part of their job description, made their navigation of the world of paper more nimble.

Stuart Corbridge and others cast the question of governance and empowerment in terms of 'sightings of the state' (Corbridge et al. 2005: 5). These authors speak of the perception of the state and its evocations in the accounts of lower-level government workers as well as of poor subjects whose encounters with local officials are widely disparate. Many of these analyses (Gupta 2012, Corbridge 2005), while they are incisive about the productive quality of the poor-state encounters in knowledge formations about an abstract entity like the state, are not very attentive to marginal subjects' grasp of the material dimensions of bureaucracies. The women I interviewed in the Govindpuri cluster were not merely forming nuanced pictures of the state on entering the domain of bail procedures and legal entitlements. In urban poor spaces, while documents were symbolically and narratively valuable in their ability to conjure everyday bureaucratic properties of the state, they were also yielding of explanations about how bureaucracies are navigated in discrete ways. Years of immersion in processes around identification documents honed certain urban poor women's ability to comprehend the immediate material resources yielded by documents (such as the ration card's relationship with bail) and the means to marshal them. But it is paramount not to mistake the accumulated pedagogies of these women as a universal, undifferentiated experience of learning for all women in the slum-women who may come from different locations, with different experiences of having lived and worked in cities, migrated with their husbands with or without work experience, subject to peculiar caste norms of patriarchy, etc.

\section{Gender, Literacy, Social Institutions and Pedagogy}

Ration cards and pensions were of immediate consequence to men as well as women. However, the men, especially if they were daily-wage labourers, maintained that they could not afford to go to these offices, forgoing the day's earnings. But this was not the only reason requiring women to familiarize themselves with the sites and protocols of bureaucratic operation. A few women spoke of how their husbands lost a limb or became enervated owing to years of strenuous work at construction sites and how, though they were at home, they could not find the strength to stand for long hours at offices to submit forms. Other men simply admitted to not 'going out that much' and pleaded illiteracy (they could not read or write Hindi or English) combined with a certain cynicism that officials favoured either those from their own caste or those with political affiliations. They depended on their educated sons and daughters or on their wives, who could draw on the pooled cultural resources of women's council meetings and other solidarities.

Women's access to bureaucracies was negotiated by their ability to confront social institutions. Some lower caste (Jatav), backward caste (Kahar/Rajput Kashyap) ${ }^{17}$ and other upper caste women (Brahmins) were prevented from going to such offices, as these 
were spaces where they had to rub shoulders with men, both literally and figuratively. Furthermore, offices which issued caste certificates, income certificates, ration cards and voter cards were all perceived to be compromised by ambiguous political morality, whereby officials struck deals with dalals (brokers) and furtively secured commissions. ${ }^{18}$ The gendered aspect of enumeration is complexly at work here..$^{19}$ One woman belonging to a backward caste was very diffident about telling me of the documents she owned, pointing repeatedly at her father-in-law and saying he was the right person to ask. Her father-in-law told me very emphatically that he would not countenance either his daughter or his daughter-in-law going to work as helps in middle-class homes or, for that matter, dealing with unscrupulous and aggressive men in places like the Sub-Divisional Magistrate's (SDM) office or the police station. When asked why he thought these spaces not to be appropriate for women, he told me how he himself had trouble acquiring certain documents - he had to pay a bribe of 5000 rupees to a dalal to procure an income and a caste certificate through official channels. 'Do you think I will trust my daughterin-law who is nursing a one-year old to these predators (read middlemen)? ${ }^{20}$ An extremely litigious man and a well-known pradhan belonging to the Scheduled Caste Jatav community in the cluster, who routinely filed Right to Information (RTI) appeals and who was approached by people from all over the neighbourhood, expressed similar reservations about his daughter's ability to navigate bureaucratic networks. He distinguished between middle class women and those residing in urban poor spaces, between those belonging to a lower caste and more forward castes in terms of access to education and bureaucratic offices. According to him, if a middle-class woman wished to be litigious, she had the cultural capital of being able to rely on various moneyed men, which was an asset needed in addition to being literate. If she was also upper caste, then her efforts would not be stymied by parochial bureaucrats who would otherwise dismiss her or mistreat her as they would recognize her caste-name. ${ }^{21}$ His daughter who wanted to work in a beauty parlour was told sternly such work was out of the question. Something more innocuous like going to school was also not entertained by the litigious father. This man who was so very rights-conscious when it came to housing entitlement, the urban poor's right to free public toilets and food security was not invested in the normative political education of his daughter.

Pedagogies of approaching paperwork and bureaucratic procedures for entitlement were inextricably linked to literacies. In theorizing literacy, scholars have pointed out its 'relational', 'culturally variable' (Collins 2003: 4) aspects and its relationship with political power (Gupta 2012: 218). There is no single literacy but multiple literacies where class, caste, geographical location, knowledge of procedures of democracy all matter (Gupta 2012: 224). Malini Ghose, reflecting on an initiative on women's literacy in the northern Indian state of Uttar Pradesh, remarks that the political context of struggles against landlords, forest contractors and water scarcity in the region, and the need to confront local power structures, had led rural women to seek both skill acquisition and literacy in the conventional sense (Ghose 2002: 1616). Conventional literacy, that is, learning to read and write in a language, has various gradations like inscribing a signature, discerning words, comprehending textual meanings and communicating what one has read and understood. In some cases, I found that 'political literacy' (Gupta 2012: 220) preceded conventional literacy and even acted as a stimulus for conventional literacy. In other words, women who pursued conventional literacy did so because they were politically aware, for instance, of the operation of nominal citizenship in bureaucratic offices that presumes universal knowledge of form-filling. Political literacy denoted the centrality of 
self-taught piecemeal pedagogies in everyday battles. Political literacy also encapsulated these women's bitter struggles with patriarchal norms and prejudices to gain conventional literacy. Female slum residents often complained that the only gendersensitive measure undertaken by the government was to pass orders that cash and food entitlements should be issued only to female heads of the household. No inroads were made by the government into the heart of the family to buffer them against unequal social relations and make their citizenship more substantive.

Some women had received a modicum of formal schooling, lived in cities earlier, and had been employed both in governmental and in non-governmental welfare bodies. ${ }^{22}$ They were, therefore, able to advise women from a situated context of deep knowledge about power structures and bureaucratic echelons. A few other women did not have the asset of even basic literacy until they married and settled down in the cluster. However, they enthusiastically enrolled themselves in adult literacy programs run by the welfare wing of a school in South Delhi and later sought to rope in others to join these programmes. Rubina, a Muslim woman in the cluster, had to hide her school-attendance from her husband who was not thrilled by the prospect of his wife disappearing in a bus to a far-off destination. He believed that the instrumental uses an education yielded, such as enabling Rubina to fill forms and interact with officials to take advantage of urban poorrelated welfare schemes, were overrated. After all, he pointed out, even by Rubina's own admission, they have not had much success in renewing a BPL card which expired in 2009. Not all of Rubina's ability to fill forms and coax officials has made much difference. But Rubina argues that it has been a while since her husband went to work-having lost his job as a construction worker-and ever since, he has lacked the self-assurance required to be resourceful in pursuing matters of enumeration. ${ }^{23}$ If she listened to him and stayed at home, she would not have had got her own daughter educated either, and the family as a whole would have had to depend on mercenary middlemen to handle their various applications. She pointed out that her husband does not take note of all the documents that they do possess-election identity card and a bank passbook included.

24 I also spoke to 5 women who were affiliated to political parties in its lower cadres who were completely unlettered but were able to push applications through offices and handle police personnel by citing influence. Supriya, a Bengali woman from a relatively upper caste Khatri community, first worked with the Bharatiya Janata Party and later the Congress party. In her thirty years in the cluster, she has helped organize rallies for both parties, adjudicated domestic disputes and participated in crackdowns on gambling in the cluster. Though Supriya could not read or write, her access to police stations, ration card offices and ration shops was made easy by her political connections. She often sent women who faced ID document-related hurdles to meet the municipal councillor who was also her political superior. Armed with recommendation letters from the councillor or accompanied by Supriya, these women were sometimes lucky enough to get information about welfare schemes, if not their applications approved. The councillor once accompanied her to a ration shop where his men slapped the shop-owner and got him to issue rations regularly. When it came to filling forms, Supriya relied on her daughter in whose education she was invested. She did not have much paper trouble in getting her daughter admitted to school, because not only were municipal schools obliging to party workers but also because birth certificates were easy to obtain, owing to the political proximity of the Sub-Divisional Magistrate's (SDM) office to councillors. ${ }^{24}$ The relationship between literacy, pedagogy and social institutions can thus be fruitfully 
engaged to explain the gendered frameworks of citizenship implicit in patriarchal structures and bureaucratic networks.

I would now like to widen the lens to trace historically enumeration technologies that may have prompted the urban poor's embrace of piecemeal and deep-seated pedagogies.

\section{Enumeration technologies over the last two decades}

In India, the 1990s are associated with the rising power of the new middle classes, trends of civil society mobilisations, aesthetic norms of the city, civic activism and the consolidation of the political power of urban neighbourhoods (Chatterjee 2004, Fernandes 2006, Ghertner 2010). Liberalisation, associated especially with the 1991 economic reforms, has implied more rigid classifications of demographic categories of the poor. The subcategories within ration cards marked APL, BPL and AAY have multiplied in the National Capital Territory (NCT) of Delhi over the last two decades. This has worrying consequences for the urban poor as those left out- especially out of the BPL classification -cannot avail of the welfare schemes that have been exclusively harnessed to this category.

In the 1990s, ration cards issued to slum residents were ensnared in a chaotic urban landscape where the access of poor people was contingent on vote-banks and middle class anxieties. The 1990 enumeration initiative of issuing documents to surveyed slum residents in Delhi was steeped in populist discourse-this exercise was undertaken after Madan Lal Khurana, a leader from a major national party in India, the Bharatiya Janata Party (BJP), sought to electorally leverage a four-year void in issuing ration cards to slum dwellers (The Hindustan Times 1990). However, when vote-banks among Delhi's slum dwellers began to steadily decline, the demand for the latter's ration cards became a diminishing return for a major national level party like the Congress, which even sanctioned a slum eviction drive of suspected illegal Bangladeshi immigrants in 1992 (Ramachandran 2003: 639). For many belonging to the middle classes, granting ration cards to slum residents legitimised illegal occupation of the city. Middle class outrage against ration cards and voter I-cards to 'undeserving migrants' spilled over in the form of Resident Welfare Association petitions in the Delhi High Court throughout the 1990s. Based on interviews with food officials, I can say that there has been some amount of administrative backing for these petitions. Following middle class protests, ration cards have been less and less privileged as claims to legitimate housing in the city.

In 2003, the rationale for the first major proposal for a national identification card termed the Multi-Purpose National Identity Card (MNIC) was framed in explicitly voiced fears of illegal immigration (Mehmood 2008). Even in this early avatar of an I-card-which included smart card features and a proposal for a national register of citizens and one of non-citizens-there was an implicit acceptance that a national identification project could be sound only if it incorporated hi-tech electronic features which clinched identity. In this sense, the MNIC project ushered in new technological sensibilities of documentation which were consciously linked to the political question of national identity and a national project of identification. Partly because the MNIC, being the first postcolonial experiment in centralized databases, came so late to India, which had already witnessed a revolution in information and communications technologies, it placed the documentation of national identity at the heart of efficient electronic identification. 
However, this early manifestation did not appeal to various actors, including corporate actors, government departments, political parties, and middle classes, whom one would think had a stake in the project. In this version of the project, the much-sought after paradigmatic shift to electronic documentation was not as pronounced as it turned out to be in later versions. This shift was visible across the various states of India. In Gujarat, smart card technology was harnessed in issuing driving licenses in 1999 (Sebastian 2008). Land records were electronically reordered in Bangalore in an e-governance project called Bhoomi (Benjamin 2007). Smart card technologies were used in the last decade in Andhra Pradesh, Rajasthan, Haryana and Chandigarh for payment of old age pensions, rural employment guarantee scheme wages, health insurance and Public Distribution System (PDS) transactions (Sebastian 2008). In 2007, a national health insurance scheme was widely implemented across the country which issued cards carrying biometric features. However, for a full-fledged national identification project to take shape, a universal rhetoric was required, at the same time compelling to powerful corporate interests, administrative classes, and seemingly inclusive of the poor. It was exactly such a rhetoric that the Unique Identification (UID) Number, also known as Aadhaar (proof) project, provided. The UID bid for an ID number issued to every national resident was justified with reference to financial inclusion, departmental linkage, enfranchisement of the undocumented, streamlining of welfare schemes and better consumer information validation. On the last point, there have been critiques of the UID that there is a palpable effort to surreptitiously replace the 'political subject' with the 'consumer citizen' (Shukla 2010: 31). The new identification project is expected to make the stored demographic information marketable, so that insurance companies and banks could use it to reduce their verification costs and attract more customers with competitive rates (Punj 2012). Middle class desires for speedy e-banking and electronic financial transactions are partly responsible for new alliances between 'the state, market and citizenship' (Shukla 2010: 31). By using terms like de-duplication and 'know your customer' (KYC) authentication as well as by placing emphasis on biometric features, the UID project seems to have tacitly accepted the premise of the MNIC project that only a sound electronic mechanism can create a credible basis of national identification. ${ }^{25}$ What does all this imply for the urban poor?

\section{The regional-national canvas of urban poor enumeration}

30 In the last decade and especially in the last five years, Delhi's slum spaces have been home to regional and national entitlement schemes that involve biometric enumeration such as direct cash transfers, free gas connections, Aadhaar and the National Population Register (NPR), which documents census information. The office of the Unique Identification Authority of India (UIDAI) has rolled out national identification numbers and the NPR has made it mandatory for all national residents to possess an NPR card with an Aadhaar number printed on it. Both these initiatives collect biometric and demographic information and claim to be indispensable to the project of making national residents legible to the state. An initiative like the UID project is, however, more than a 'state simplification' in James Scott's sense of making societies more governable (Scott 1998: 2). The UID is expected to increase commercial profitability for banks and insurance companies, microfinance companies and supermarket dealers, some of which regard the 
poor as 'target markets' (Maringanti 2009: 37). The Aadhaar numbers are part of an ambitious project to integrate various regional and national government schemes and services. The UIDAI authorities, issuing these numbers in the form of slips, claim to have distributed 200 million numbers and hope to reach the target of an estimated 600 million by 2014 (The Business Standard 2012). This number was sought to be made indispensable for acquiring BPL ration cards, the opening of bank accounts, subsidized food grains, free gas connections and old age pensions. ${ }^{26}$

31 My fieldwork demonstrates that possession of an Aadhaar card did not mean that slum residents automatically received any or all of these services. BPL cards for those staying in slums in Delhi were issued periodically and cards could not be automatically renewed. No fresh cards in slum clusters were made in the previous 3-4 years nor were cards renewed during this period. Ration cards for slum residents could be issued afresh only once in five years under the periodic scheme announced for them. This constraint was introduced in order to conform to the central government's cap pertaining to the number of BPL cardholders, which is presently pegged at $409,000 .{ }^{27}$ Those residing in slums applying for any card between 2008-2009 (when cards were issued) and 2014 (the year when cards are expected to be renewed) were not considered. In addition, the Food and Supplies Department in Delhi passed an order for a biometric review (unlinked to the Aadhaar card scheme) in 2009 which required all cardholders residing in slums to submit their fingerprints and photographs failing which their cards would be cancelled. ${ }^{28}$ Though this order was supposed to be sent by speed-post to all card-holders, published in newspapers and conveyed in person by Food Inspectors, many BPL slum residents were clueless about the review and did not appear for it. Their cards were cancelled without much ado. Interestingly, this independent biometric review will be rendered irrelevant when the periodical scheme to issue fresh BPL cards is expected to be announced in 2014 -at this time, fresh cards will be made whose information will be aligned with the Aadhaar card, which all applicants are expected to possess. ${ }^{29}$ Residents are expected to keep track of all these often-unrelated bureaucratic bursts of verification activity, to acquire new cards, and to submit information afresh! The failure to do so would be immediate, so that slum residents would not be eligible for exclusive welfare schemes such as subsidized food grains and LPG gas connections (in lieu of kerosene oil) available only to certain classes of poor ration cardholders.

\section{Pedagogies of gendered citizenship}

32 In late February 2013, when I visited the ration office in Kalkaji less than a kilometre away from the cluster, some of the women waiting there for hours to talk to food officials were unable to comprehend why their ration cards were not being renewed. In the face of impatient officials and incoherent official information, residents were forced to approach aspiring political leaders, councillors, NGOs and brokers. Confronted with the nonissuance of BPL cards in slum clusters for the last few years, not even these local actors could be much use. Besides, these actors could not always be trusted: they often had ulterior motives and their presence in the slum was usually short-term. What remained available to the residents were pedagogies of enumeration accumulated over years, if not decades, of engagement with different authorities over welfare benefits. But these piecemeal pedagogies were not always adequate in understanding what lay behind the inexorable denials of entitlement by the central and state governments, whose officials 
were preoccupied with the esoteric business of integrating and making compatible various databases of the urban poor. These denials must be read alongside gendered relations in the cluster.

The various enumerative experiences constituted pedagogic process of learning about citizenship, welfare practices and urban governance. At the ration office where many of the dejected women had struck up a conversation among themselves, they drew intricate connections between the denial of ration card, corruption, the lack of female security in the cluster and their repeated failure to gain urban citizenship. The women on this occasion staked out a discourse of gendered citizenship where they traced non-functional educational degrees and the failure to renew their ration cards with the crushing of their daughters' aspirations. Radha, who could not renew her ration card and feed her family of one husband and five children, said that both her daughter and her niece had passed their high school examination but had failed to get any government assistance..$^{30}$ In her words and in the words of Rupa, another resident of the cluster at the ration office:

Our girls who want to move up in life, something should happen for them! How can they fulfil their aspirations in the future? [My daughter] is now sitting at home. Wherever she goes, for service, for a balwadi job, for a job in a Company, to earn from home, even that requires ghus (bribery), only then things happen. ${ }^{31}$

They also pointed out that by failing to issue them a ration card, the government had forced them to prioritise between buying food in the open market in the age of inflation, and buying a sturdy door to keep away aggressive men who hung around their houses and kept molesting their daughters and female relatives. This denial of ration assistance rankled even more in the face of the failure of these educated girls to get jobs or scholarships without a bribe. The same woman who described her daughter and niece's predicament of failing to get any government assistance then told me that she was tempted to give both the girls away in marriage. Her plans were thwarted, however, by a high dowry price wherever she went. Through narratives of the ID document, they associated citizenship with exclusionary frameworks. They believed that the government failed to provide as well as adequately enforce gender-specific benefits within urban poor schemes, and did not see them as related to issues of female security in liminal spaces of legality. When quizzed about the Aadhaar initiative, they felt that this was at best a verification exercise, and one that had not rendered the government more responsive to slum residents or improved the educational chances of lettered girls.

\section{Conclusion}

This article has sought to provide a gendered, nuanced contribution to the literature on enumeration and identification documents, which has otherwise been somewhat skewed in favour of men, even while unpacking dominant categories like citizens, the poor, refugees and aliens (Bakewell 2007, Gordillo 2006, Koster 2013, Torpey 2000). I began this paper with a story of one woman's thwarted attempts to not merely acquire a document but to enfranchise herself, implicit in her desire to be counted as dilli ki gareeb nagarik. Her quest for proof and thereby entry into the city was fraught with a plenitude of factors like the administrative wrangling over the socio-economic definition of BPL, the bureaucratic investment in norms of stable urban residence and official indifference to patriarchaly compromised women. But this paper is not just a lengthy remark on structural hurdles of a culturally imbued postcolonial bureau that impinge on documentary processes. It also 
records women relentlessly schooling themselves in the best means available to procure a document, lay claim to welfare benefits and to mobilise knowledge-resources. Urban poor women's piecemeal pedagogies around bureaucratic procedures and enumerative processes, though interesting in themselves, should be seen as an entry point into their thick engagements with and navigations of the city, social institutions, and the mutable relationship between material proofs and entitlement processes.

\section{BIBLIOGRAPHY}

Anjaria, Jonathan Shapiro (2011) 'Ordinary States: Everyday Corruption and the Politics of Space in Mumbai', American Ethnologist, 38(1), pp. 58-72.

Appadurai, Arjun (2001) 'Deep Democracy, Urban Governmentality and the Horizon of Politics', Environment and Urbanization, 13(2), pp. 23-43.

Bakewell, Oliver (2007) 'The Meaning and Use of Identity Papers: Handheld and Heartfelt Nationality in the Borderlands of North-West Zambia', Working Papers, Oxford: International Migration Institute.

Ghose, Malini (2002) 'Literacy, Power and Feminism', Economic and Political Weekly, 37(17), pp. 1615-1620.

Gordillo, Gaston (2006) 'The Crucible of Citizenship: ID-Paper Fetishism in the Argentinean Chaco', American Ethnologist, 33(2), pp. 162-176.

Benjamin, Solomon; Bhuvaneswari, R.; Rajan, P.; Manjunatha (2007) 'Bhoomi: ‘E-Governance', Or, An Anti-Politics Machine Necessary to Globalize Bangalore?' Working Paper, Collaborative for the Advancement of Studies in Urbanism through Mixed Media.

Chandola, Tripta (2012) 'Listening into Others: Moralising the Soundscapes in Delhi', International Development Planning Review, 34(4), pp. 391-408.

Chatterjee, Partha (2004) The Politics of the Governed, Delhi: Permanent Black.

Collins, James (2003) Literacy and Literacies: Texts, Power and Identity, Cambridge: Cambridge University Press.

Corbridge, Stuart; Williams, Glynn; Srivastava, Manoj; Veron, Rene (2005) Seeing the State: Governance and Governmentality in India, New York: Cambridge University Press.

Ghertner, D.A. (2010) 'Calculating without Numbers: Aesthetic Governmentality in Delhi’s Slums', Economy and Society, 39(2), pp. 185-217.

Gupta, Akhil (2012) Red Tape: Bureaucracy, Structural Violence and Poverty in India, New Delhi: Orient Blackswan.

Jha, Preeti (2008) ‘Great Wall of Kalkaji’, The Indian Express, 6 April.

Koster, Martijn (2013) 'Fear and Intimacy: Citizenship in a Recife Slum, Brazil', Ethnos: Journal of Anthropology, URL: http://dx.doi.org/10.1080/00141844.2012.732955. 
Maringanti, Anant (2009) 'Sovereign State and Mobile Subjects: Politics of the UIDAI’, Economic and Political Weekly, 44(46), pp. 35-40.

Mehmood, Taha (2008) 'Notes from a Contested History of National Identity Card: 1999-2007', South Asia Citizens Web, URL: http://www.sacw.net/article391.html.

Punj, Shweta (2012) ‘A Number of Changes'. Business Today, 4 March.

Shukla, Ravi (2010) ‘Reimagining Citizenship: Debating India’s Unique Identification Scheme’, Economic and Political Weekly, 45(2), pp. 31-36.

Scott, James (1998) Seeing like a State: How Certain Schemes to Improve the Human Condition have Failed, New Haven \& London: Yale University Press.

Sebastian, P.T. (2008) ‘The Card Trick’, Outlook Business, 3 May.

Srivastava, Sanjay (2012) 'Duplicity, Intimacy, Community: An Ethnography of ID Cards, Permits and Other Fake Documents in Delhi', Thesis Eleven, 113(1), pp. 78-93.

Tarlo, Emma (2003) Unsettling Memories: Narratives of India's 'Emergency', Delhi: Permanent Black.

The Business Standard. 2012. 'UID Targets to Enroll 40 cr People for Aadhar cards: Nilekani', 21 August.

The Hindustan Times. 1990. 'Khurana hails PM's Decision', 2 January.

The Hindustan Times. 1990. 'Ration Cards for Slum-Dwellers', New Delhi, 2 January.

Torpey, John (2000) The Invention of the Passport: Surveillance, Citizenship and the State, Cambridge: Cambridge University Press.

\section{NOTES}

1. The rigorous comments I obtained at the presentation of an early draft of this paper at Centre de Sciences Humaines (CSH) went a long way in giving shape to arguments. I thank Marie-Hélène Zérah, Veronique Dupont, Jules Naudet, Gilles Verniers, Jayani Bonnerjee, Ravi Sundaram and Vikramaditya Sahai for their thoughtful ideas. I would also like to thank Radhika Govinda and the four anonymous reviewers of SAMAJ for their elaborate suggestions and CSH for financial assistance in writing this paper.

2. The ration card system in India can be traced to late colonial rule when the rationing of miscellaneous items was introduced as a wartime measure to protect cities from starvation and dissidence. Post-independence, similar systems were sporadically reintroduced.

3. Post 2000, classifications of Above the Poverty Line and Below the Poverty Line based on socioeconomic indices which were introduced into ration card discourse.

4. Shweta, a resident of Govindpuri cluster, interview by author, 6 February 2013.

5. I do not pit these literacies against each other but I argue that they should be seen as part of a bundle of knowledge-resources mobilized by women.

6. In 2012, the total number of jhuggis or slums, as given by the landowning agency and Delhi's housing authority, Delhi Development Authority (DDA), was 2,500 in Bhoomiheen camp spread across 29,813 square metres and 5000 in Navjeevan and Nehru camp put together across 45,342 square metres: see Delhi Urban Shelter Improvement Board (DUSIB) list of JJ clusters on their official website, www.delhishelterboard.in, accessed on 4 April 2013.

7. The first phase of fieldwork was carried out as part of my PhD work between January and May 2011 and the second phase was undertaken as part of my postdoctoral research between January and June 2013. 
8. One such demolition was to construct a five-foot wall separating the cluster from surrounding middle-class colonies (Jha 2008).

9. For more information on datelines prescribing eligibility and resulting in exclusions vis-à-vis slum resettlement, see Dupont's paper in this volume.

10. From 2010 onwards, a new agency called the Delhi Urban Shelter Improvement Board (DUSIB) was set up which took over the Slums and Jhuggi and Jhopri (JJ) Department. DUSIB now surveys slum clusters along with the landowning agency and determines the need for slum relocations or to be upgraded in-situ. The Delhi government issued a series of resolutions approving the construction of flats instead of plots under a scheme called the Jawaharlal Nehru National Urban Renewal Mission (JNNURM). Govindpuri cluster is not a priority in DUSIB's list of slum clusters marked for demolition under the JNNURM, I learnt through a Right to Information response. One survey of Govindpuri cluster was carried out by DUSIB along with the landowning agency, DDA in 2012.

11. $\mathrm{N}^{\circ} . \mathrm{F} .3(1) / 99-\mathrm{F} \& S$ (P\&C)/119, Specified Articles (Regulation of Distribution) Amendment Order, 1999.

12. Within the expanded definition of AAY, these cards are issued to vulnerable sections of Indian society like households headed by widows, terminally ill, disabled people, those aged 60 and above, and slum residents.

13. Annexe to the Public Distribution System (Control) Order, 2001, Gazette of India, Extraordinary, Part II, Section 3 (i). All ration cards issued after 2001 mention that the card cannot be used for purposes other than withdrawal of rations.

14. Parmeela Rakhi, interview by author, New Delhi, 10 March, 2011.

15. Gyanvati Sharda, interview by author, New Delhi, 10 March 2011.

16. Asha clinic is a welfare body located in the cluster.

17. They are classified not as Scheduled Castes but under the Other Backward Classes category.

18. One respondent from the Jatav community told me that he had to file a Right to Information plea, make complaints to higher authorities and wait for three years before he could procure a caste certificate from the Sub-Divisional Magistrate's (SDM) office. Shyamprasad, interviews by author, New Delhi, 11 April 2013.

19. For other instances of gendered configurations of caste, see Govinda's paper in this issue.

20. Rajdeep Kashyap and his daughter-in-law, Ishita, a resident of Govindpuri slum cluster, New Delhi, 11 April 2013.

21. Gangadhar, a resident of Govindpuri slum cluster, 21 March 2013.

22. See Dupont's paper in this volume for more on government and non-government assisted meetings on negotiating marginality.

23. Rubina, a resident of Govindpuri slum cluster, interview by author, 16 May 2013.

24. Supriya, a resident of Govindpuri slum cluster, Interview by author, 2 August 2013.

25. The UID Authority of India (UIDAI) has been careful publicly to steer away from controversial themes like illegal migration and terrorism and instead highlight its attempts to provide a documentary infrastructure to the poor.

26. If the Aadhaar numbers were earlier made out to be compulsory for every government service, in September 2013, the Supreme Court ruled otherwise. In addition to striking down the mandatory linkage of these cards to government subsidies and services, the Supreme Court also ordered the government not to issue these cards to illegal migrants. This move poses a formidable challenge especially to the Delhi government's plans to link the Aadhaar card with cash transfer schemes meant for the urban poor.

27. Circular F.No.3(1)/2009/P\&C/488 dated 3/12/2009, Food and Supplies Department, Delhi.

28. F.3 (1)/2009/P\&C/488 dated 3/12/2009. The biometric review was conducted as much to verify residence as to substantiate identity as it was presumed that when the cardholder appeared for such verification, he/she would also bring his/her ration card thereby providing 
proof of residence. The review was announced on 3 December 2009 and the deadline set at 30 June 2010. It may be relevant to note that the scheme for issuing fresh BPL cards was started before the biometric review in February 2009. It was possible that people got fresh cards made but had failed to submit biometric information and, therefore, had their cards cancelled. Food and Supply Officer (FSO), interview by author, New Delhi, 28 March 2013.

29. Food and Supply Officer, interview by author, New Delhi, 28 March 2013.

30. This woman told me that she had applied for financial assistance (and received no response) under the Delhi Government's ladli scheme which provides instalments of money to girl children at various stages of their education.

31. Rupa and Radha, interview by author, 28 February 2013.

\section{ABSTRACTS}

This paper argues that the various encounters of female slum residents residing in Delhi's margins with identification documents shape certain instrumental and symbolic forms of knowledge about the city. Urban poor women's encounters with identity documents produce 'piecemeal pedagogies' in which these women try to educate themselves and each other about bureaucratic channels and application procedures in and through handling documents. Such encounters also yield thick knowledge about the city and gendered frameworks of access and entitlement. The arguments about the pedagogic process are made through an assessment of various forms of literacy complicated by unequal social relations. This paper frames the pedagogies of ID documents in the lives of the city's urban poor over the last two decades, which have been marked by shifting technologies of enumeration.

INDEX

Keywords: urban poor, gender, enumeration, pedagogy, identity documents, entitlements.

\section{AUTHOR}

\section{TARANGINI SRIRAMAN}

Postdoctoral Fellow in Urban Dynamics, Centre de Sciences Humaines (CSH), New Delhi 